\title{
EFEITO ALELOPÁTICO DO EXTRATO ETANÓLICO E DAS FRAÇÕES OBTIDAS DAS FOLHAS DE Smilax sp. SOBRE Allium cepa (CEBOLA)
}

\author{
Juliana C. Fonseca*, Myriam A. Barbosa, Izabela C. A. Silva, Ana H. F. \\ Castro, Luciana A. R. dos Santos Lima
}

Universidade Federal de São João Del Rei-UFSJ - Campus Centro-Oeste Dona Lindu - Divinópolis/MG.

*E-mail: julianacostafonseca@hotmail.com

\section{Resumo}

Alelopatia é a capacidade de liberar substâncias obtendo efeito de uma planta sobre a outra, que seja estimulante ou inibidora, por meio da produção de compostos químicos. A salsaparrilha ou japecanga, como é conhecida popularmente, possui cerca de 30 espécies no Brasil, onde somente o gênero Smilax é encontrado. O presente estudo teve como objetivo avaliar o potencial alelopático do extrato etanólico e das frações obtidas das folhas de Smilax sp. sobre radículas e hipocótilos de Allium cepa (cebola). Folhas de Smilax foram coletadas, secadas e trituradas. Após a obtenção das frações hexânica, diclorometânica, acetoetílica e hidroetanólica por meio da partição dos seus respectivos solventes com o extrato etanólico, obtido por percolação com etanol, foi realizado o ensaio de atividade alelopática feito com sementes de Allium сера. $\mathrm{O}$ crescimento das sementes foram conduzidos em solução tampão MES [ácido 2-(N-morfolino) etanosulfônico] na concentração de 1,95 g/L e cada fração foi testada em concentrações diferentes ( 200, 100 e $50 \mu \mathrm{g} / \mathrm{mL}$ ). Foram distribuídas 25 sementes em cada uma das placas de petri e, posteriormente, adicionadas, separadamente, as amostras diluídas em $7 \mathrm{~mL}$ de solução tampão. No grupo controle adicionou-se $7 \mathrm{~mL}$ de solução tampão. As placas foram incubadas por 10 dias em Câmara de Germinação, a $25{ }^{\circ} \mathrm{C}$. Dessa forma, o crescimento das radículas e dos hipocótilos foi medido. Os resultados obtidos no experimento mostraram maior inibição do hipocótilo com o extrato etanólico e fração hexânica na concentração de $200 \mu \mathrm{g} / \mathrm{mL}$. Em relação à radícula, a fração diclorometânica obteve maior porcentagem de inibição na concentração de 200 $\mu \mathrm{g} / \mathrm{mL}$. O extrato etanólico e as frações de Smilax sp. apresentaram efeito alelopático sobre radículas e hipocótilos de Allium cepa (cebola). 
Palavras-chave: Smilax, efeito alelopático, cebola.

Apoio financeiro: CNPq, FAPEMIG e UFSJ.

Fonseca, Juliana C.; Barbosa, Myriam A.; Silva, Izabela C. A.; Castro, Ana H. F.; Lima, Luciana A. R. dos Santos; "EFEITO ALELOPÁTICO DO EXTRATO ETANÓLICO E DAS FRAÇÕES OBTIDAS DAS FOLHAS DE Smilax sp. SOBRE Allium cepa (CEBOLA)", p. 49-50 . In: Anais da V Jornada Acadêmica Internacional de Bioquímica [= Blucher Biochemistry Proceedings, v.1, n.1]. São Paulo: Blucher, 2015. DOI 10.5151/biochem-jaibqi-0029 